\title{
Birthweights of babies born at home in a black rural community of Bophuthatswana, southern Africa
}

\author{
B D RICHARDSON, R E SINWEL, J M RANTSHO, M BAC, AND M MOATSHE
}

Epidemiology Section, National Research Institute for Nutritional Diseases, Medical Research Council, Johannesburg; Gelukspan Hospital, Bophuthatswana

SUMmary In Africa, data on incidence of babies' low birthweight are based virtually exclusively on information derived from deliveries in hospitals. The incidence of low birthweight is about double that prevailing in developed countries. However, in a rural region in southern Africa, after painstakingly overcoming local strongly entrenched custom, it was found possible to organise the measurement of newborn babies born at home. It was found that the incidence of low birthweight was about half of that among babies born in hospitals - that is the proportion was similar to that of developed populations.

In southern Africa in black rural communities, as with many third world populations, babies are often delivered at home. There is little doubt that a child's birthweight is 'universally, and in all population groups, the single most important determinant of the chances of the newborn to survive'. Yet, the same WHO report ${ }^{1}$ admits that 'data on birthweight are extremely rare, and often non-existent' particularly in those countries where the 'proportion of low birthweight is the highest'. This statement is supported by Eveleth and Tanner ${ }^{2}$ who found a lack of data on birthweight in their surveys of anthropometry for many countries of the third world. It has been estimated by $\mathrm{WHO}^{1}$ that ' 21 million babies born throughout the world in 1979 were of "low birthweight" weighing $2500 \mathrm{~g}$ or less'.

In an attempt to overcome some of this serious lack of data, birthweights have been obtained in a typical developing community. Studies on babies born at home are being made in a rural area in Bophuthatswana, southern Africa. This is a hot, dry area situated in the maize-growing belt and is typical of a third world agricultural community where many of the men are away from home as migrating workers and the women eke out an existence on the farmlands. In this region studies conducted in the area serving the hospital showed that $60 \%$ of the women delivered at home, the remainder in the local hospital, or in one of its 7 peripheral clinics or mobile clinic. These clinics are not as well supported as the hospital authorities would wish and mothers are free to choose whether to have their babies in the hospital or clinic, or at home in the traditional manner. In many black African communities access to the mother and baby immediately after birth is taboo because of local custom. Hence it was necessary, by careful explanation, to persuade regional and local authorities of the urgent need to secure birthweight data. It was owing to the good relationship between the authorities and the local leaders that sufficient trust was engendered to make the study possible.

\section{Customs surrounding a birth in a black community}

A close relative, usually an older woman, for instance mother or grandmother, is the only birth attendant. No other person may enter the lying-in (delivery) hut until the infant's cord has fallen off, a period of 10 days. During this period the mother is strictly confined to the hut, recovering from the birth and establishing close contact with her infant. She does not leave the hut, or participate in any of the day-to-day chores. Her sole task is to feed the infant; her attendant washes the baby and attends to all the mother's needs. Once the cord is off the mother may leave the hut for toilet purposes and the father only then may see and handle the infant. The mother must however, remain confined to the hut for a further 1 to 2 , or even 3 months, her sole responsibility the new baby; relatives care for any other children she may have.

The same situation pertains in the urbanised black community, except that the baby has more than likely been born at a hospital or clinic. As soon as she returns home, after 1-3 days, the mother 
is confined to her room, which is occupied solely by herself, her new infant, and her attendant until the cord has fallen off. Only after this may the father see and handle the infant. Handwork-such as sewing, knitting, crochet, traditional crafts etc, or reading - can be done during this period, otherwise there is complete rest. Once the obligatory 1 to 3 months' period has passed she can resume an active role in the day-to-day activities and routine of the home.

Because of such a strictly adhered to custom it was with great difficulty, and after much searching, that an area was found where traditional barriers could be overcome sufficiently, and enough trust engendered, to allow the acceptance of local workers, who were given permission to enter the birth hut to weigh and measure newborn infants.

\section{Subjects and method}

After the local government had been consulted, and the need for data on birthweights of newborn babies been carefully explained, local areas could be approached. The Gelukspan area of Bophuthatswana is served by the Gelukspan hospital and the maternity cases from the area comprised the hospital study group. Although clinics were operative in some of the villages they were not extensively used by the population, as shown by the fact that some $60 \%$ of women still deliver at home in these villages. The home birth study group was drawn from five villages within the Gelukspan area, particularly selected as there were as yet no established clinics. Twelve women were selected by their local chiefs, headman, and clinic committees to be trained to weigh newborn infants at home in each of the five selected areas. These women were committee members, mainly middle-aged, highly motivated, and respected. Some came from larger villages and others from smaller ones; the larger having 2 or 3 workers as houses are scattered. None of the women had had any previous training. The population of the villages chosen consisted of about 100000 inhabitants, of which about one-tenth comprised the study group. Mothers were asked to report the birth of their babies to the local workers and to participate in the birthweight study. There was no selection or pressure on the part of the workers and as such the mothers represent a random sample from each area. Birthweights of all births reported were recorded within 24 hours, the majority within the first 12 hours. Many were weighed immediately after birth if the worker was called in time. Babies born at the hospital were weighed at birth or at least within the first 12 to 24 hours.
Workers were trained in the maternity ward of the local Gelukspan hospital to weigh newborn babies with spring-type scales with a fish-net for holding the infant. They were taught to tare the scale with the fish net, or other suitable holding cloth before weighing on each occasion. These scales are not ideal but are easily carried in a pocket or handbag, which was considered essential as the worker must often walk long distances to the homes. Once the women were accepted by their communities and the project had been running successfully for about 6 months they were taught to measure length and head circumference of the newborn infants, using glassfibre tape measures. As a measuring board is cumbersome to carry, the worker, with the mother's or attendant's assistance, placed the baby on a flat surface in the supine position. By holding her record book firmly against the head, her assistant extending the infant's legs by pressing the knees down, and using another book, or similar object placed at the feet, the distance between head and heel was marked on the bed sheet, measured, and recorded. The baby's head, around the largest occipitofrontal circumference, was also measured. On several occasions, during regular meetings at the hospital, weighing and measuring techniques were checked.

Altogether 672 babies have now been weighed, and a smaller sample-namely 89-have had length and head circumference measured. Data relating to time of birth and time weighed, as well as mother's age and state of health, duration of pregnancy, numbers of previous children, and any deaths were recorded. In the latter part of the study stillborn babies were also weighed and measured, with the exception of those already buried before the worker arrived. The proportion of stillbirths recorded for home births was $1.5 \%$.

Hospital birthweights (890) were recorded for the same period from the hospital maternity register; a further small sample of 174 had length and head circumference measured. At the hospital, stillbirths represented $2 \cdot 8 \%$ of births, but none was weighed.

\section{Results}

The percentage distribution of women having 1 , $2-4$, or more than 5 children for both home and hospital deliveries is presented in Table 1. Table 2 shows mean birthweights of black babies born at home compared with those born at the local hospital. Table 3 shows mean birthweights within parity groups of black babies born at home compared with those born at the local hospital. In Table 4 the prevalences of low birthweight $(<2500 \mathrm{~g})$ 
both for home and hospital deliveries are given. In Table 5 the mean birthweight, length, and head circumferences are shown for black infants born at home and in hospital.

Of the women comprising the study group $27 \%$ were primapara, $28 \%$ were grand multipara $(\geq 5$ births), and $45 \%$ multipara; and of hospital deliveries $47 \%$ were primapara, $18 \%$ were grand multipara, and $35 \%$ were multipara. Significantly more younger mothers delivered at hospital and older ones preferred to deliver at home, but both groups are considered to be at risk, making the

Table 1 Percentages of women according to parity groupings for home and hospital deliveries

\begin{tabular}{llll}
\hline & $\begin{array}{l}\text { Primapara } \\
(\%)\end{array}$ & $\begin{array}{l}\text { Multipara } \\
(\%)\end{array}$ & $\begin{array}{l}\text { Grand multipara } \\
(\%)\end{array}$ \\
\hline Home births & $27 \cdot 2$ & $45 \cdot 1$ & $27 \cdot 5$ \\
Hospital births & $46 \cdot 6$ & $35 \cdot 1$ & $18 \cdot 3$ \\
\hline
\end{tabular}

Table 2 Mean birthweights of home compared with hospital deliveries

\begin{tabular}{lccc}
\hline & Home & Hospital & Significance \\
\hline Number of subjects & 650 & 904 & \\
Mean birthweights (g) & 3332 & 3024 & $\mathrm{P}<0.001$ \\
Standard deviation & 644 & 586 & \\
\hline
\end{tabular}

Table 3 Mean birthweights in parity groupings of home compared with hospital deliveries

\begin{tabular}{llll}
\hline & \multicolumn{3}{l}{ Mean birthweight $(g)$} \\
\cline { 2 - 2 } & Primapara & Multipara & Grand multipara \\
\hline Home births & $3199 \pm 642$ & $3424 \pm 670$ & $3320 \pm 603$ \\
& $(185)$ & $(294)$ & $(193)$ \\
Hospital births & $2956 \pm 557$ & $3116 \pm 589$ & $3026 \pm 661$ \\
Significance & $(432)$ & $(315)$ & $(143)$ \\
\hline
\end{tabular}

Table 4 Prevalence of low birthweight $(<2500 \mathrm{~g})$ for home compared with hospital deliveries

\begin{tabular}{lll}
\hline & Hcme & Hospital \\
\hline Number of subjects & 672 & 890 \\
Percentage with low birthweight $<2500 \mathrm{~g}$ & $7 \cdot 1$ & $14 \cdot 4$ \\
\hline
\end{tabular}

Table 5 Mean birthweight, length, and head circumference of black infants born at home and in hospital

\begin{tabular}{|c|c|c|c|}
\hline & $\begin{array}{l}\text { Birthweight } \pm S D \\
(g)\end{array}$ & $\begin{array}{l}\text { Length } \pm S D \\
(\mathrm{~cm})\end{array}$ & $\begin{array}{l}\text { Head } \\
\text { circumference } \pm S D \\
(\mathrm{~cm})\end{array}$ \\
\hline $\begin{array}{l}\text { Home } \\
\text { Hospital }\end{array}$ & $\begin{array}{l}3332 \pm 644 \\
(n=672) \\
3024 \pm 586 \\
(n=890)\end{array}$ & $\begin{array}{l}46 \cdot 8 \pm 4 \cdot 3 \\
(n=89) \\
47 \cdot 8 \pm 3 \cdot 5 \\
(n=174)\end{array}$ & $\begin{array}{l}35 \cdot 1 \pm 2 \cdot 2 \\
(n=89) \\
34 \cdot 1 \pm 2 \cdot 0 \\
(n=174)\end{array}$ \\
\hline
\end{tabular}

SD = standard deviation. percentages at risk $55 \%$ for home births and $65 \%$ for hospital deliveries. The overall percentages of mothers at risk were similar and show that the two study groups were more or less equally distributed and thus comparable.

Mean birthweight has been found to be significantly higher $(\mathrm{P}<0.001)$ for home, $3332 \pm 644 \mathrm{~g}$, compared with the 890 hospital deliveries, $3024 \pm 586 \mathrm{~g}$. Significant differences were also apparent across the various parity groupings, as shown in Table 3. In both home and hospital deliveries multipara had significantly higher mean birthweights than primapara $(P<0.001)$, but not compared with grandmultipara. Primapara and grandmultipara showed no significant differences in the mean birthweights for either home or hospital deliveries. Among the 672 babies weighed at home prevalence of low birthweight $(<2500)$ was $7 \%$, compared with that of those born at the local Gelukspan hospitalnamely, $14 \%$.

\section{Discussion}

The mean birthweight of babies delivered in hospital is similar to that reported for other parts of Africa, ${ }^{13-7}$ Central American Indians, ${ }^{8}$ and poor USA blacks. ${ }^{9}$ The low birthweight prevalence of babies born at home $(7 \%)$ is closely similar to that of Western communities $(6-8 \%)^{\mathbf{1 0}-13}$ whereas that for the hospital is similar to other areas of Africa. This indicates the probable source of present world data for developing countries-namely, that deriving from hospital records as can be seen in Table 6 which sets out the comparative birthweights and prevalences of low birthweight, together with those of the present studies on home and hospital populations.

Table 6 Comparative mean birthweights and percentages of low birthweight

\begin{tabular}{|c|c|c|c|}
\hline & $\begin{array}{l}\text { No of } \\
\text { subjects }\end{array}$ & $\begin{array}{l}\text { Birthweight } \\
\pm S D \\
(\mathrm{~g})\end{array}$ & $\begin{array}{l}\text { Low } \\
\text { birthweight } \\
(\%)\end{array}$ \\
\hline \multicolumn{4}{|l|}{ Black } \\
\hline Africa 1 & & 2900 & $15 \cdot 0$ \\
\hline $\begin{array}{l}\text { Dar es Salaam } 3 \\
\text { Nigeria } 4\end{array}$ & 16532 & $\begin{array}{l}2991 \pm 488 \\
3090\end{array}$ & $\begin{array}{l}15 \cdot 2 \\
13 \cdot 6\end{array}$ \\
\hline Northern Nigeria 5 & 20648 & $3030 \pm 450$ & $15 \cdot 8$ \\
\hline Yoruba, Ibadan 6 & 10839 & $2922 \pm 550$ & \\
\hline Southern Rhodesia*7 & 1000 & 2807 & $16 \cdot 6$ \\
\hline Poor black USA 9 & 768 & $2972 \pm 553$ & \\
\hline Central American Indians ${ }^{8}$ & 302 & $2946 \pm 464$ & \\
\hline Home deliveries & 672 & $3332+646$ & $7 \cdot 1$ \\
\hline Hospital deliveries & 890 & $3024 \pm 586$ & $14 \cdot 4$ \\
\hline \multicolumn{4}{|l|}{ White } \\
\hline Europe1 & & 3200 & $8 \cdot 0$ \\
\hline North America 1 & & 3200 & $7 \cdot 0$ \\
\hline Britain 1011 & & 3415 & $6 \cdot 7$ \\
\hline USA $^{1213}$ & & 3400 & $6 \cdot 1$ \\
\hline
\end{tabular}

*Now Zimbabwe. 
The significantly higher birthweights of babies born at home was surprising, as the impression is that malnourished mothers and therefore small babies are to be expected in rural Africa. That this was not so in Bophuthatswana is an encouraging finding and if true for other third world populations would ease the world situation in regard to reducing high prevalences of low birthweight of newborn infants in communities that cannot afford the technologically advanced techniques operative in developed areas. ${ }^{1}$

\section{Conclusion}

This would seem to be the first attempt to obtain information on weights of babies born at home in a rural developing community. It is of considerable interest that significantly more younger mothers are choosing to have their babies in the hospital, rather than in the traditional manner at home. If the finding in regard to babies born at home is also true of home births in other developing populations, the estimated prevalences of low birthweights are too high. Obviously further studies must be carried out in a wide variety of areas. The knowledge obtained could well modify the policies suggested by WHO authorities, aimed at reducing the incidence of low birthweights and regarded as often requiring 'methods which are beyond the economic and technological resources of most developing countries'. ${ }^{1}$

\section{References}

1 World Health Organisation, Division of Family Health. The incidence of low birthweight. A critical review of available information. World Health Stat $Q$ 1980; 33: 197-224.

2 Eveleth P B, Tanner J M. Worldwide variation in human growth. Cambridge: Cambridge University Press, 1976: 341.

${ }^{3}$ Boersma E R, Mbise R L. Intrauterine growth of liveborn Tanzanian infants. Trop Geogr Med 1979; 31: 7-19.

4 Ebrahim G J. Epidemiology of low birth weight in East Africa. East Afr Med J 1969; 46: 102-6.

5 Rehan N E, Tafida D S. Birth weight of Hausa infants in Northern Nigeria. Br J Obstet Gynaecol 1979; 86: 443-9.

6 Effiong C E, Laditan A A O, Aimakhu V E, Ayeni O. Birthweights of Nigerian children. Niger Med J 1976; 6: 63. Cited by N E Rehan and D S Tafida, 1979.

7 Houghton J W, Fraser Ross W. Birth weights and prematurity rates in Southern Rhodesia. Trans $R$ Soc Trop Med Hyg 1953; 47: 62-5.

8 Belizán J M, Delgado H, Mejia-Pivaral V, Valverde V, Klein R E. Criteria for selection of communities in poor rural areas with high risk of low birth weight babies. J Trop Med Hyg 1981 ; 84: 243-8.

9 Rush D, Stein Z, Susser M. A randomized controlled trial of prenatal nutritional supplementation in New York City. Pediatrics 1980; 65: 683-97.

10 Butler N R, Alberman E D, eds. In: Perinatal problems. Edinburgh: Livingstone, 1969.

11 Crosse V M. The preterm baby, seventh edition. London: Churchill Livingstone, $1971: 2$.

12 Schaffer A J, Avery M E. Diseases of the newborn, third edition. Philadelphia: Saunders, 1971:15.

13 Bain K, Hubbard J P, Pennell M Y. Hospital fatality rates for premature infants. Pediatrics $1949 ; 4: 454-60$.

Correspondence to Dr B D Richardson, Epidemiology Section, National Research Institute for Nutritional Diseases, Medical Research Council, PO Box 91157, Auckland Park 2006, Johannesburg, South Africa.

Received 26 October 1982

\section{Notice to contributors}

Please note that revised guidelines for the submission of manuscripts have been printed inside the front cover of this journal and, in particular, that two copies of papers should be submitted. 